\title{
Land Suitability Assessment for Soybean (Glycine max (L.) Merr.) Production in Kabwe District, Central Zambia
}

\author{
Prisca Munene ${ }^{1}$, Lydia M. Chabala ${ }^{1} \&$ Alice M. Mweetwa ${ }^{1}$ \\ ${ }^{1}$ Department of Soil Science, School of Agricultural Sciences, University of Zambia, Lusaka, Zambia \\ Correspondence: Prisca Munene, Department of Soil Science, School of Agricultural Sciences, University of \\ Zambia, P.O. Box 32379, Lusaka, Zambia. E-mail: priscamunene@yahoo.com
}

Received: November 29, 2016

Accepted: January 21, 2017 Online Published: February 15, 2017

doi:10.5539/jas.v9n3p74

URL: http://dx.doi.org/10.5539/jas.v9n3p74

\begin{abstract}
Soybean (Glycine $\max$ (L.) Merr.), is a high value crop that can generate income for households. As a legume, soybean is incorporated in cropping systems to improve soil fertility. Soybean productivity is however limited by factors including declined soil fertility, climate change and partly due to inadequate land suitability information. This study aimed at identifying suitable land for soybean production in Kabwe district. Data layers of selected attributes relevant to soybean production were generated with slope and wetness data layers extracted from the digital elevation model (DEM). Elevation was used as a proxy for climate (rainfall and temperature) and was generated by reclassifying the elevation grid into elevation classes. Data layers for soil reaction $(\mathrm{pH})$, soil organic carbon, phosphorus and texture were generated by inverse distance weighting interpolation method based on soil point data. A distance to roads layer was created using the euclidean distance tool. A spatial process model based on multi-criteria evaluation was used to integrate data layers in a weighted sum overlay to generate a soybean suitability map, whose quality was assessed using an error matrix. Results showed that $15.07 \%$ of the investigated area was highly suitable for soybean production, whereas $26.53 \%$ was suitable and $25.18 \%$ was moderately suitable. The other $20.57 \%$ was marginally suitable, $10.74 \%$ was currently not suitable and $1.92 \%$ was permanently not suitable. Based on ground truth data, the overall classification accuracy of the suitability map was $65 \%$. The map was therefore good enough for use as a guide in selecting suitable sites for soybean production.
\end{abstract}

Keywords: attribute, data layer, soybean, suitability

\section{Introduction}

Soybean (Glycine max. (L.) Merr.), is a high value crop whose grain consists 40 percent protein, 20 percent oil and 34 percent carbohydrates. It is used in the production of oil, human food and stock-feed. Soybean is a leguminous plant mostly grown in the temperate and sub-tropical regions (Muliokela, 1995). It is usually incorporated in cropping systems to improve soil fertility and increase yields. This leads to increased crop production, further resulting in increased food security and income generation (Lubungu et al., 2013; Tembo \& Sitko, 2013). There is potential for soybean production in Zambia, however productivity is usually limited by many factors that include climate change, decline in soil fertility, low availability of improved seed and low usage of microbial inoculum. Other factors limiting soybean productivity include limited availability of inputs, expertise and market opportunities. In 2014/2015 farming season, the area planted to soybean in Zambia increased by $11.2 \%$, however, its national yield rate declined by $5 \%$ due to factors such as the late on set of the rains, poor crop management practices and low soil fertility (NAIS, 2015; MAL, 2016).

To address the challenges of soybean productivity, technologies such as improved seed varieties, crop rotations and tillage practices, inoculation, use of herbicides, pesticides, fungicides and fertilizers have been introduced at most farmers fields. While these technologies are intended to improve soybean productivity, the availability of soil suitability information when selecting production sites is also key for increased productivity (Sullivan, 2003; Adornado \& Yoshida, 2008). Land suitability assessment for soybean production is therefore relevant, otherwise implementing new and improved technologies will have no positive impact on soybean production.

Land suitability assessment (LSA) is a tool for classifying suitable areas by assessing land qualities, matching them with requirements of a specific land utilization type (Food and Agriculture Organization [FAO], 1976; FAO, 1983; FAO, 2007; Mustafa et al., 2011). It is used as an agricultural planning tool for identification of suitable 
areas to grow crops as well as identify the main limiting factors for agriculture production. The systems used in assessing land suitability allow for the integration of different criteria that affect suitability. These include soil, rainfall, temperature, topography and other non-biophysical factors such as social, economic and political governance aspects. Land suitability assessment is therefore a complex process and such complexities lead to the simultaneous use of several decision support tools such as Geographic Information Systems (GIS) and multi-criteria decision analysis (MCDA), which are inevitable in determining suitable land for crop production (Malczewski, 2004, 2006; Mendas \& Delali, 2012).

The process of land suitability analysis for crop production using a GIS based multi-criteria approach first involve the selection of criteria relevant for growing a particular crop. Data layers are generated for each of the selected criteria and thereafter, relative weights are assigned to each data layer. The weighted data layers are used as inputs in a weighted overlay analysis, culminating into land suitability maps (Bolstad, 2005; Perveen et al., 2013).

Traditionally in Zambia, land suitability assessment for crop production is conducted through surveys. The Zambia Semi-Quantified Land Evaluation System for rainfed agriculture is used to assess land suitability. This system incorporates physical and chemical properties of the soil, climatic conditions of the location and the farmer's ability to manage the land for crop production. The system further predicts the potential yield of the crop cultivated (Kalima \& Veldkamp, 1985; Veldkamp, 1987; Woode, 1988). According to Chinene (1991), this system is very good for recognizing the limitations of land. Prior to this system, the Land Capability Classification System (LCCS) was used to assess land suitability for rainfed crops, only that it emphasizes soil physical properties more than the chemical status of the soil. A study by Clayton (1974) applied the LCCS in which the extent of the soil suitable for Virginia tobacco and maize were assessed. Woode (1979) also applied the LCCS to assess the suitable area for the rural reconstruction center. Other studies that applied the LCCS include that of English (1982) and Sokotela (1982).

Despite the land evaluation studies that have been done in Zambia, the information in the final reports is not available to most farmers, to assist them in decision making concerning site selection. At times, the land suitability information available does not effectively represent the conditions of most farmers' fields because the suitability assessments were done on a large scale. Farmers are therefore left to plant crops anywhere without considering suitability issues, further leading to low crop productivity. The use of fast methods to map land suitability for crop production is also important considering the effects of climate change on some land qualities (Elsheikh et al., 2013). A GIS based multi-criteria approach in assessing land suitability for soybean production therefore becomes key. Kalima and Veldkamp (1985) also recommended a computerized system in land evaluation to reduce on the number of calculations which were done manually.

This study was therefore aimed at evaluating land suitability for rainfed soybean production in Kabwe district by integrating relevant variables of soil, climate and topography using a GIS based multi-criteria approach. The study aimed at generating a suitability map that could be used as a guide in decision making for selecting suitable sites for soybean production in the area.

\section{Materials and Methods}

The study was carried out in Kabwe district located in central Zambia. Attributes relevant for soybean production were identified from the literature search and reviews, and these include slope, drainage, soil reaction, rainfall, temperature, soil organic carbon, phosphorus and texture. Accessibility was also included since it determines the ease of crop movement and market access.

Data layers for slope and drainage (wetness) were extracted from the digital elevation model (DEM) using appropriate algorithms in ArcGIS. Elevation was used as a proxy for climate (rainfall and temperature) and was generated by reclassifying the elevation grid into elevation classes. The distance dataset was generated using the euclidean distance tool. Data sets for soil parameters were generated by inverse distance weighting (IDW) based on soil samples collected from the field. A spatial process model based on multi-criteria evaluation was used to integrate selected spatial attributes in a weighted sum overlay to generate a soybean suitability map. The quality of the suitability map generated was assessed using an error matrix. The following sections describe in detail what was involved at every stage of the methodology.

\subsection{Description of the Study Area}

Kabwe district (Figure 1) is located approximately $130 \mathrm{~km}$ north of Lusaka. It lies between Latitude $14^{\circ} 28^{\prime} 0^{\prime \prime} \mathrm{S}$ and Longitude $028^{\circ} 25^{\prime} 5^{\prime \prime}$ E. The district covers an area of about $1,570 \mathrm{~km}^{2}$ and it is connected to Lusaka and other surrounding districts by rail line and the Great North Road. 
Kabwe district has a sub-tropical climate that changes with altitude. The average altitude in the district is $1207 \mathrm{~m}$ above sea level. The weather pattern is determined largely by the movement of the Inter-Tropical Convergence Zone (ITCZ) resulting in three seasons. There is a cool dry season from April to August, a hot season from September to October and a rainy season from November to April. The average annual temperature is $31{ }^{\circ} \mathrm{C}$ with mean monthly maximum of $36^{\circ} \mathrm{C}$ and the mean monthly minimum of $7{ }^{\circ} \mathrm{C}$ (Kabwe Municipal Council, 2010; Zambia Meteorological Department [ZMD], 2015). The district falls within agro ecological region IIa receiving between $800 \mathrm{~mm}$ and $1000 \mathrm{~mm}$ of rainfall. The average total rainfall received in the district is $966 \mathrm{~mm}$, which occur during the rainy season. Due to the high temperatures, evapotranspiration is higher in the district and it usually exceeds precipitation.

The soils in the district comprise of Acrisols and Luvisols. These are described as moderately leached reddish to brownish clayey to loamy soils, derived from acid rocks, and moderately leached red to reddish clayey soils derived from basic rock, often in admixture with acid rocks respectively. These soils largely influence the drainage system of the area and they range from strongly to slightly acid. The major river draining Kabwe district is Mulungushi River which borders with Kapiri Mposhi district in the eastern part. Other rivers are Chitakata, Kalonga, Munga, Chankwankwa, Chapya, Mpima and Natuseko. These are the main tributaries to Mulungushi River. The district is characterized by open woodlands type of vegetation which is mainly miombo woodland. Chipya, munga, termitaria and grassland types of vegetation are also found in the area. The relief is gently undulating plateau with gently sloping interfluve crests that are usually flat. The shoulders and middle slope are convex with moderate slope ranging between 1 to 3 percent.

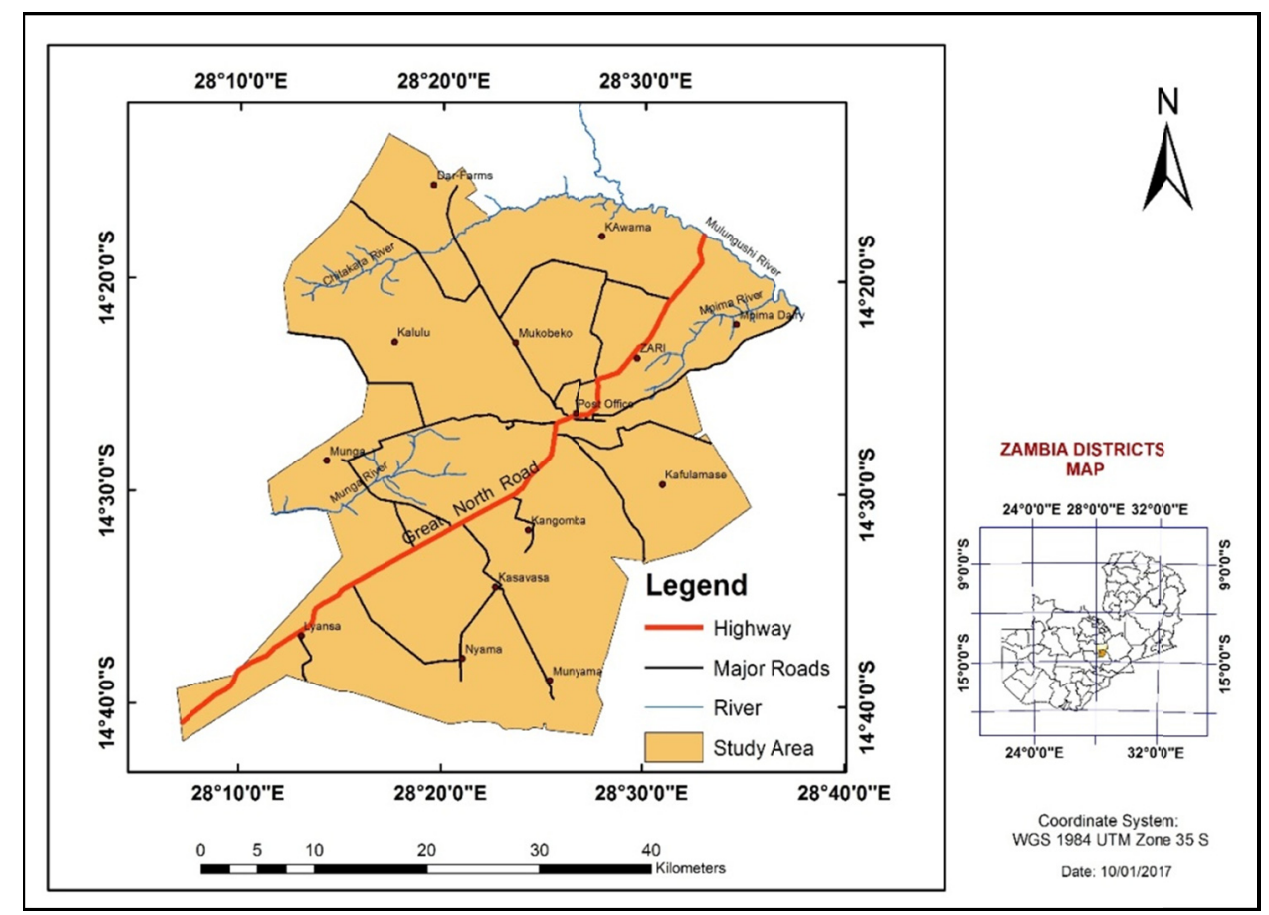

Figure 1. Map showing the study area

\subsection{Identification of Attributes Relevant to Soybean Production}

The attributes relevant to soybean production were identified through a literature search and reviews (Dugje et al., 2009; Rutherford, 2010; Kanangi et al., 2013). In addition, soybean crop production guides available from the Ministry of Agriculture (MoA) were also reviewed (Ministry of Agriculture [MoA], 2002). Based on this review, eight biophysical spatial attributes were identified. These include soil texture, soil reaction $(\mathrm{pH})$, soil organic carbon (SOC), phosphorus (P), rainfall, temperature, slope and drainage. In addition, accessibility was included as a layer since it determines the ease of crop movement and market access. 


\subsection{Data Sources}

Data layers for the selected attributes relevant to soybean production were prepared from secondary and primary data sources. The sources of data sets include topographic maps obtained from Ministry of Lands and Natural Resources (MLNR), the national soil map of Zambia obtained from the Soil Survey Section of the Zambia Agriculture Research Institute (ZARI), and a $90 \mathrm{~m}$ resolution Shuttle Radar Topography Mission (SRTM) downloaded from the United States Geological Survey (USGS) website (http://earthexplorer.usgs.gov). The SRTM DEM was covering an area between Latitude $14^{\circ} 25^{\prime} 42^{\prime \prime} \mathrm{S}$ and Longitude $028^{\circ} 27^{\prime} 05^{\prime \prime}$ E. Soil samples were randomly collected in the study area as primary data in order to generate data layers for selected soil attributes. A GIS software was used to process the data layers for use in the land suitability process model.

\subsection{Preprocessing of Digital Elevation Model}

The DEM was first loaded into ArcMap and projected to World Geodetic System 1984 (WGS, 1984) UTM Zone $35 \mathrm{~S}$ coordinates. It was then preprocessed to remove sinks related to imperfections in the data before extracting slope and drainage. A preprocessing method by Chabala et al. (2013) was followed where the flow direction was first extracted using the flow direction tool. A raster of sinks was then created by enabling the sink tool with flow direction used as the input flow direction raster in the table. This was followed by the creation of a sink area raster by enabling the watershed tool. At this stage, the extracted flow direction was the input flow direction raster and the sinks as the feature pour point data or input raster. The zonal statistics tool was then used to create a raster of the minimum elevation in the watershed of each sink, with sink area as the input raster or feature zone data. The DEM was used as the input value raster and sink minimum as the output raster. When creating the sink minimum, statistics type was set to minimum and value as the zone field. The zonal fill tool was then used to create a raster of the maximum elevation with sink area as the input zone raster and the DEM as the input weight raster. Further, the minus tool was then used to subtract the minimum value from the maximum value to find the sink depth, with sink maximum as the first input raster and the sink minimum as second input raster. Finally the fill tool was applied to the DEM with the $\mathrm{Z}$ value set to the sink depth to generate a DEM with all the sinks in it filled.

\subsection{Process Model for Soybean Suitability Mapping}

The overall flow of the methodology followed in this study as presented in the process model (Figure 2) involved the selection of attributes relevant to soybean production, generation of data layers, weighting and overlaying of the data layers to generate a land suitability map for soybean production. The data sets for the soil variables were generated with inverse distance weighting interpolation method, based on soil samples collected from the field. Data sets for topographic variables were generated from the DEM using various algorithms in ArcGIS. Elevation dataset was used as proxy for climatic variables (rainfall and temperature) and it was generated by reclassifying the DEM. The distance dataset representing accessibility was generated using the euclidean distance tool.

Each data layer was reclassified into suitability classes based on soybean requirement. The suitability levels assigned to each dataset were defined based on literature, expert knowledge, observation and practical experiences. The suitability levels were ranked as highly suitable, suitable, moderately suitable, marginally suitable, currently not suitable and permanently not suitable based on the suitability classification structure of the Food and Agriculture Organisation [FAO] (FAO, 1976, 1983, 2007). The datasets generated were finally combined using the weighted sum overlay to generate the land suitability map for rainfed soybean production. 


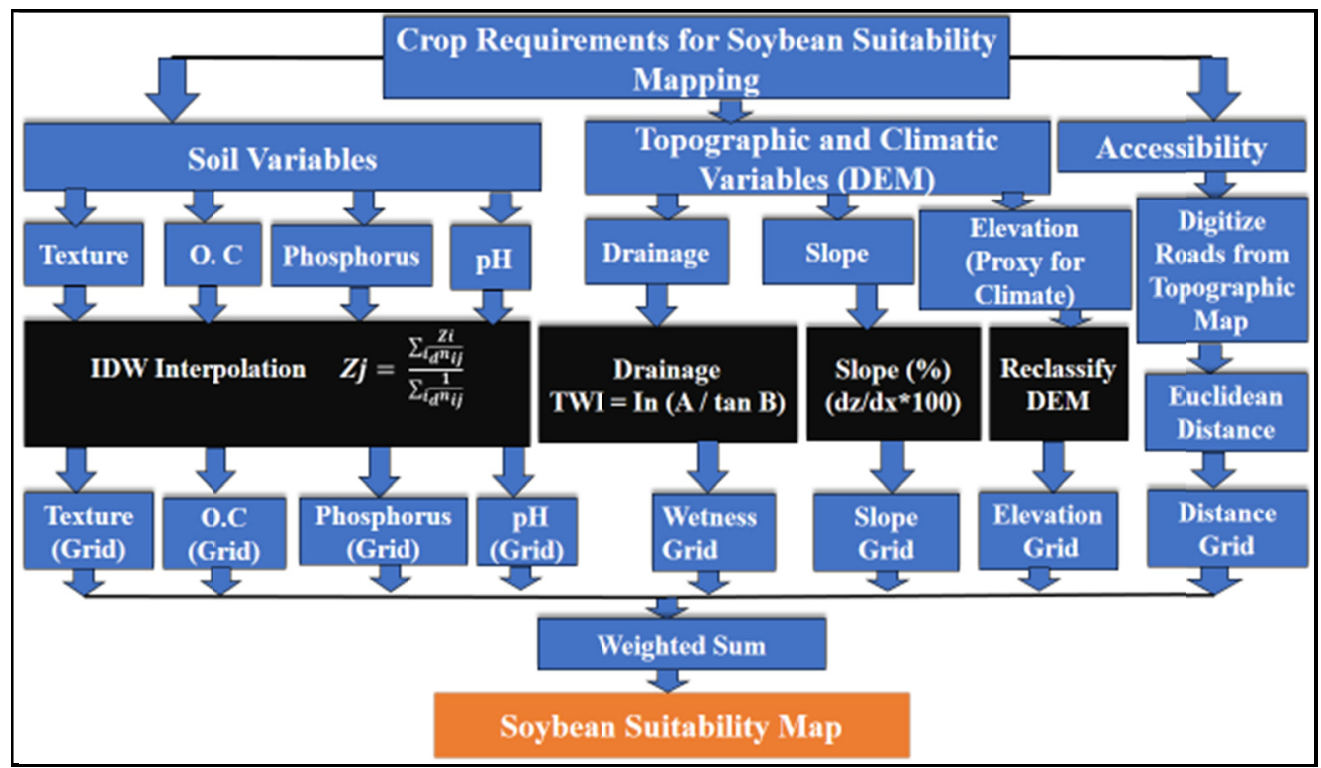

Figure 2. Process model showing the methodology of the study

\subsection{Data Collection and Preparation of Datasets}

\subsubsection{Slope}

Slope is an important topographic factor in land suitability mapping, acting as a guide to land management and risk of erosions. It is described as a measure that indicates the change in steepness or inclination of a given surface over the horizontal plane and can be expressed in degree or percentage (Wilson \& Gallant, 2000; Chabala et al., 2013).

In this study slope was extracted from the filled DEM following a method by Chabala et al. (2013). The slope value was calculated in percentage and the $Z$ value was set to one. The extracted slope dataset was reclassified into six classes according to their suitability for soybean production (Figure 3). Every cell in the output raster had a slope value where the lower slope value indicated a flatter terrain and higher values the steeper terrain. Flat fields having smooth surface were identified as better for soybean production as they facilitates even and equal distribution of water.

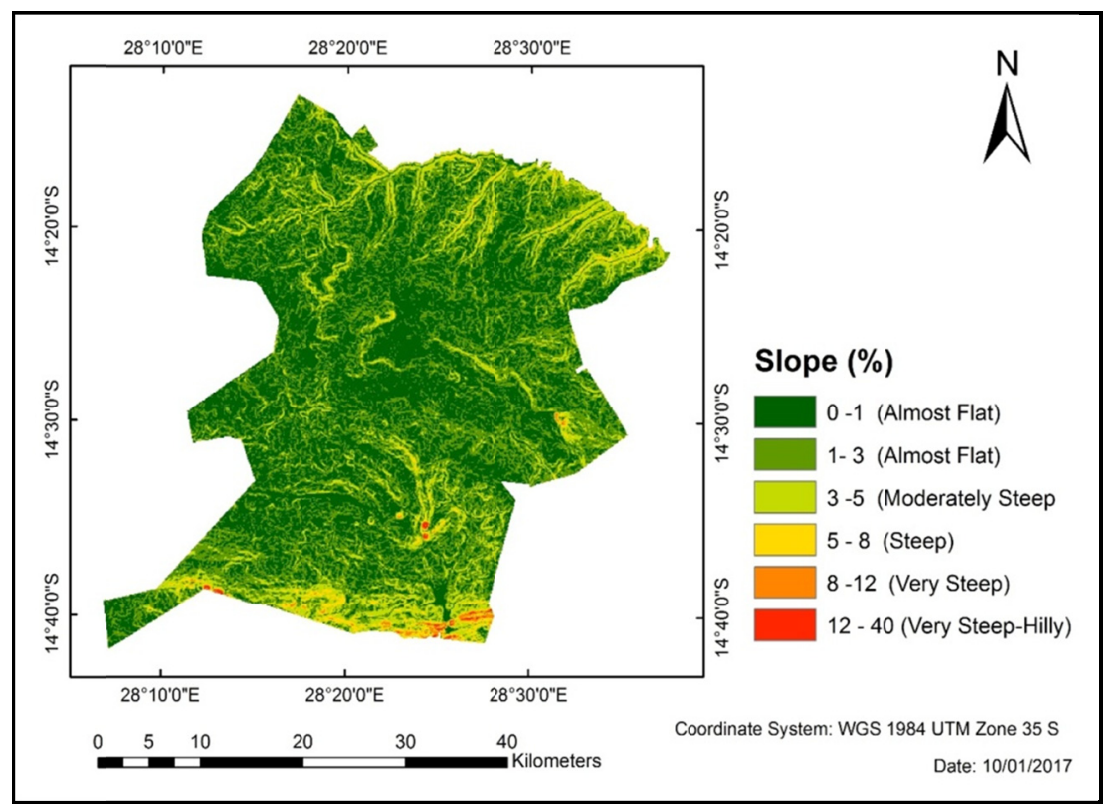

Figure 3. Extracted slope of Kabwe 


\subsubsection{Drainage (Wetness Index)}

Drainage is another important topographic factor in land suitability analysis, giving an indication of the soil moisture conditions of an area. In this study, soil drainage was represented by topographic wetness index which is a steady state wetness index reflecting soil moisture and drainage conditions. Topographic wetness index (TWI) is defined as a function of the natural algorithm of the ratio of local upslope contribution area to slope angle (Beven \& Kirby, 1979; Wilson \& Gallant, 2000). It is said to be valid for areas where there are substantial amounts of lateral water movement and vertical flow (Schmidt \& Persson, 2003). This was the case in the study area and hence the appropriateness of using it to represent drainage. Equation 1 was used to calculate TWI where A was representing the area of flow accumulation in square meters, and B was representing slope in radians.

$$
\mathrm{TWI}=\ln (\mathrm{A} / \tan \mathrm{B})
$$

To extract the area of flow accumulation (A), the flow direction was first extracted from the DEM using the flow direction tool. This tool was used to indicate the flow direction of water out of each cell in the DEM. Flow accumulation was then calculated by enabling the flow accumulation tool with flow direction dataset being the input. The final value of A was calculated by multiplying the generated flow accumulation grid within the area. Slope was converted from degrees to radians using the raster calculator based on Equation 2.

$$
\text { Slope in Radians }=\text { Slope in degrees } \times \pi / 180
$$

The cells which had no data values in the wetness index grid were reclassed to zero using the raster calculator as indicated in the expression below.

\section{Con (IsNull(“WetnessIndex”),0,”WetnessIndex”)}

The generated wetness index grid (Figure 4) was classified into five classes according to their suitability for soybean production.

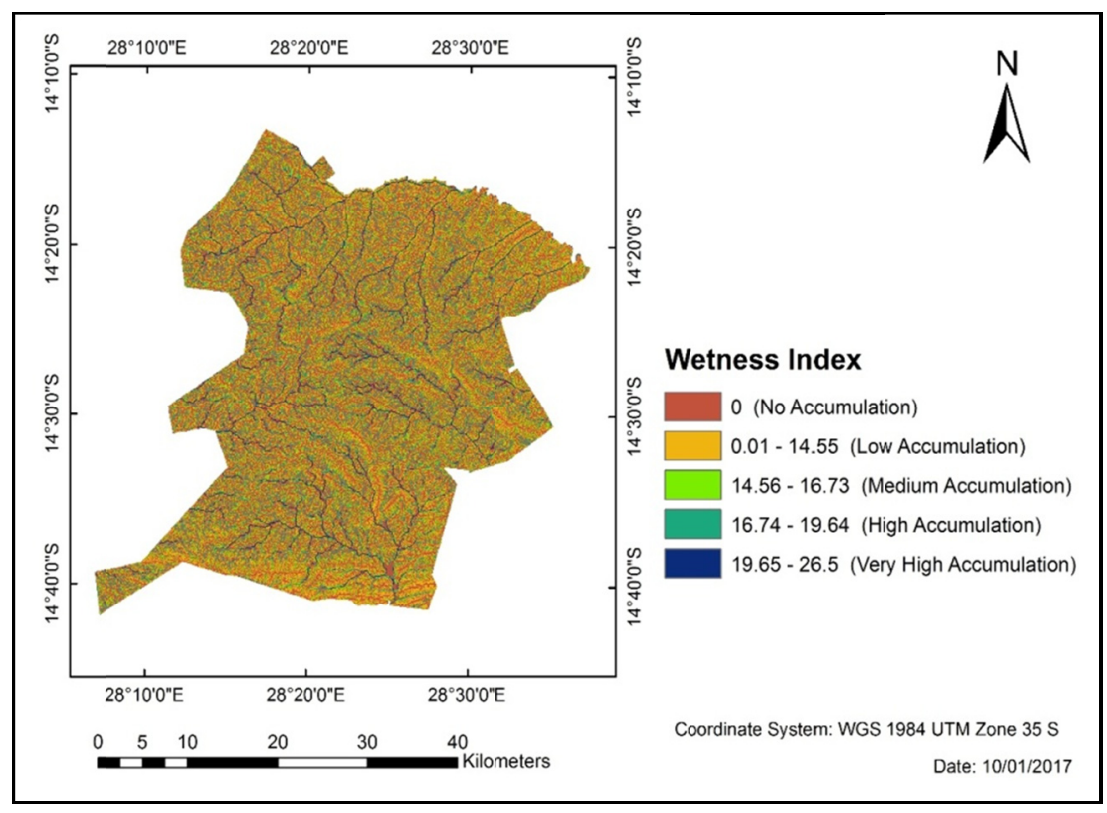

Figure 4. Generated wetness index representing soil drainage in Kabwe

\subsubsection{Elevation: Proxy for Climate (Rainfall and Temperature)}

Climate affects the growth, developments and yields of agricultural crops favorably or unfavorably. Soybean requires a range of temperature between $20{ }^{\circ} \mathrm{C}$ and $30{ }^{\circ} \mathrm{C}$ with an optimum of $22{ }^{\circ} \mathrm{C}$ and about $500-1000 \mathrm{~mm}$ of rainfall for its production (MoA, 2002; Kanangi et al., 2013). In this study, elevation was used as a proxy for climatic variables (rainfall and temperature) due to limited rainfall and temperature data for the study area. It is also a well-known principle that the micro-climate of an area can be related to elevation (Subarna et al., 2014). Higher elevation areas are generally characterized with extreme weather conditions, having high rainfall and 
cooler temperatures. The void filled DEM was therefore reclassified into four elevation classes representing levels of suitability for soybean production (Figure 5).

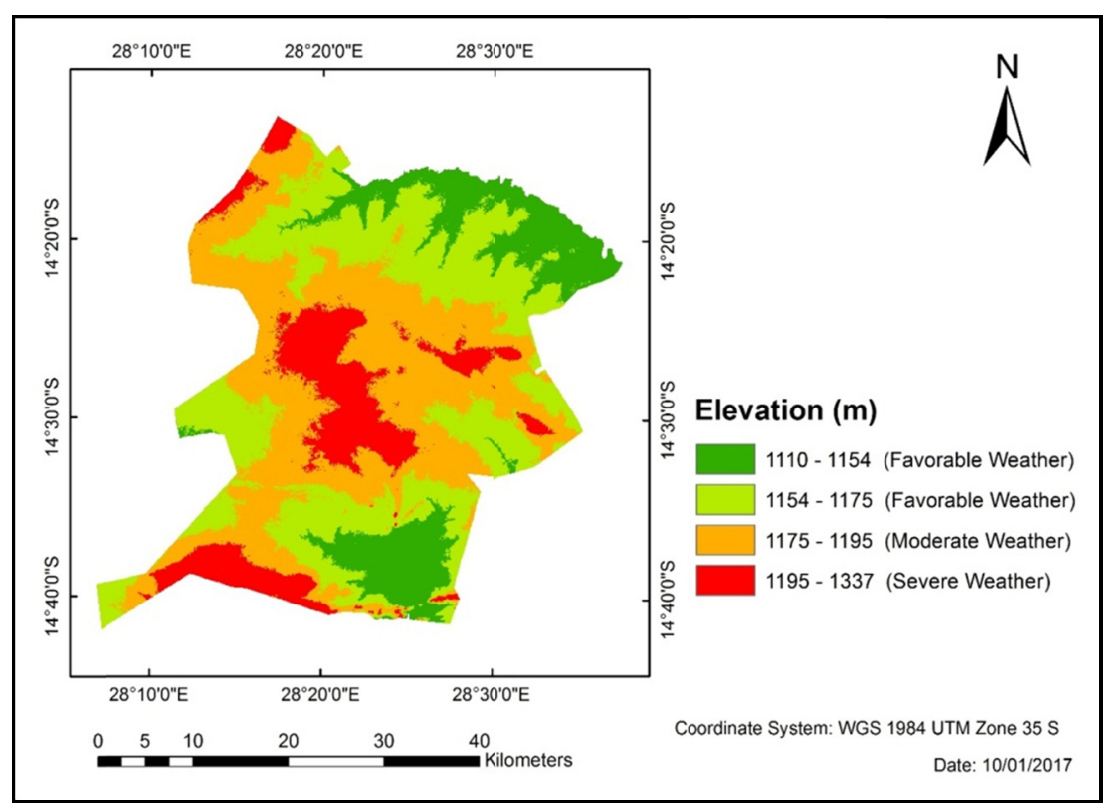

Figure 5. Elevation a proxy for climate (rainfall and temperature)

\subsubsection{Soil}

Soil is an important raw material, providing anchorage and nutrients to crops. A knowledge of the chemical and physical characteristics of soil is important in land suitability analysis and mapping for soybean production. In this study, a field survey was undertaken due to limited soil data from secondary sources. Soil sampling was conducted using random sampling method. Soil samples were collected at a depth of 0-20 cm from 92 sampling sites. The soil samples were analyzed for soil reaction $(\mathrm{pH})$, soil organic carbon $(\mathrm{SOC})$, phosphorus $(\mathrm{P})$ and texture. Texture was represented by clay proportions in the soil. The coordinates at each sampling point together with the corresponding analyzed soil data were imported into ArcMap where IDW interpolation method was applied to generate a surface for each soil attribute based on Equation 3. This method allowed for the prediction of values for cells in a raster from a limited number of sample points.

$$
Z_{j}=\frac{\sum_{i} \frac{Z_{i}}{d^{n}{ }_{i j}}}{\Sigma_{i} \frac{1}{d^{n}{ }^{n}}}
$$

In this equation, $Z_{j}$ is the estimate value for the unknown point at location $j, d_{i j}$ is the distance from a known point $i$ and $n$ is the user defined exponent (Bolstad, 2005). The default of 15 maximum and 10 minimum neighboring points was used with each of the predicted maps set to Kabwe district boundary as the processing extent in geo-processing environments. The prediction maps were classified into classes according to their suitability in soybean production (Figure 6; Figure 7; Figure 8; Figure 9). 


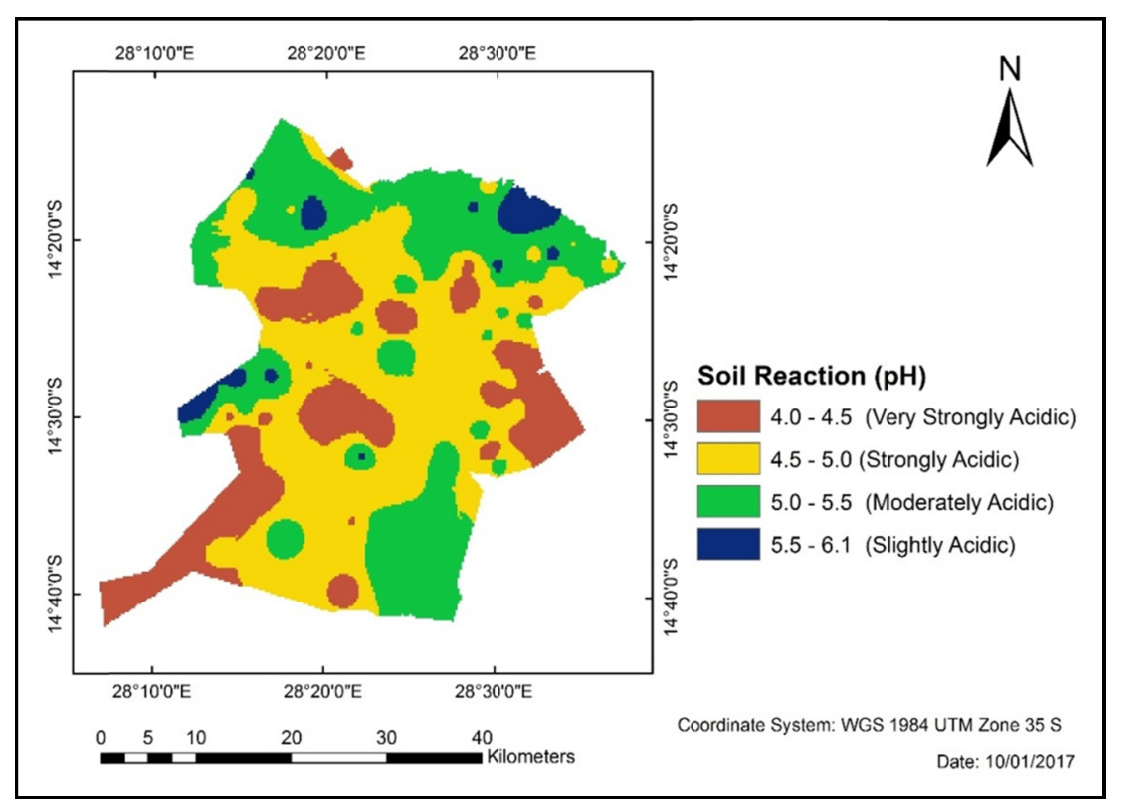

Figure 6. Spatial variability of soil reaction $(\mathrm{pH})$ in Kabwe

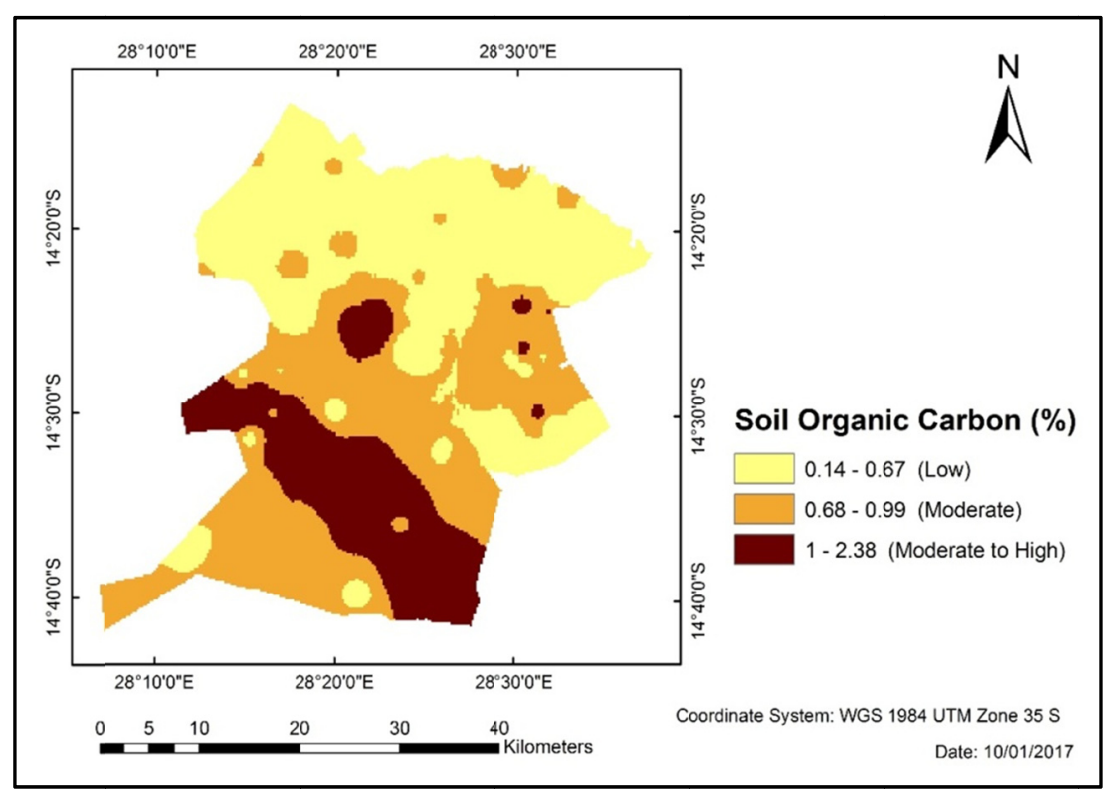

Figure 7. Spatial variability of SOC in Kabwe 


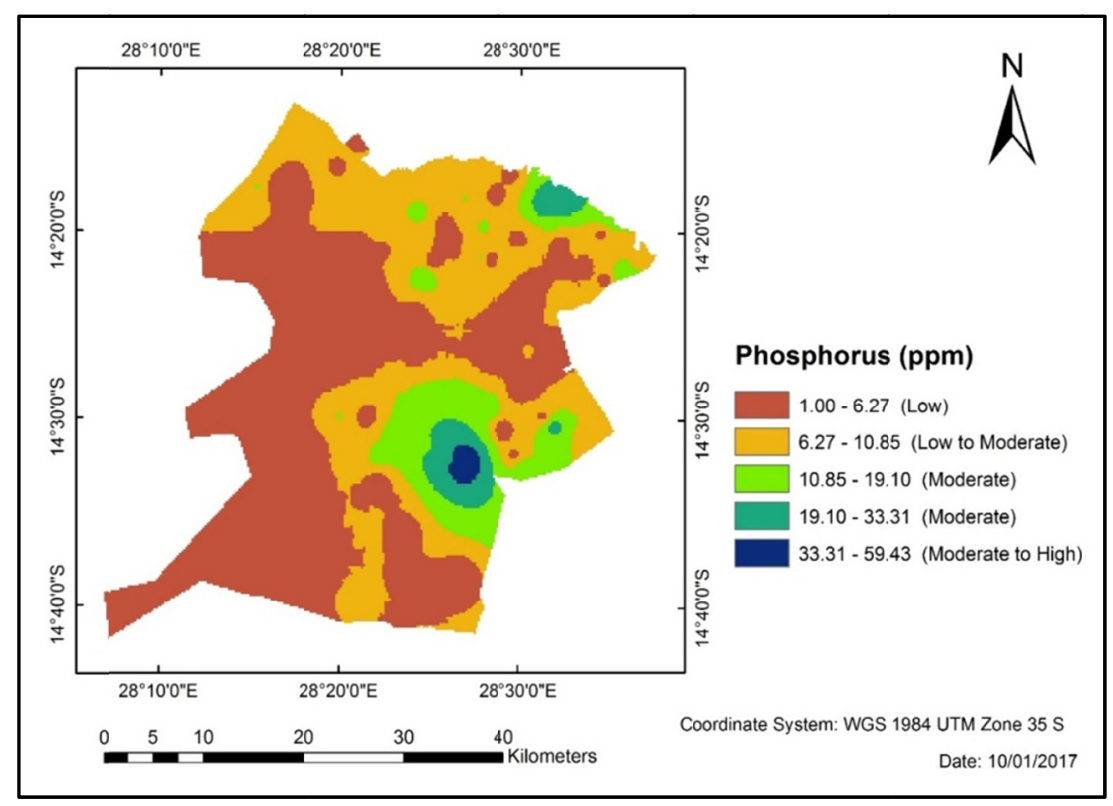

Figure 8. Spatial variability of available phosphorus in Kabwe

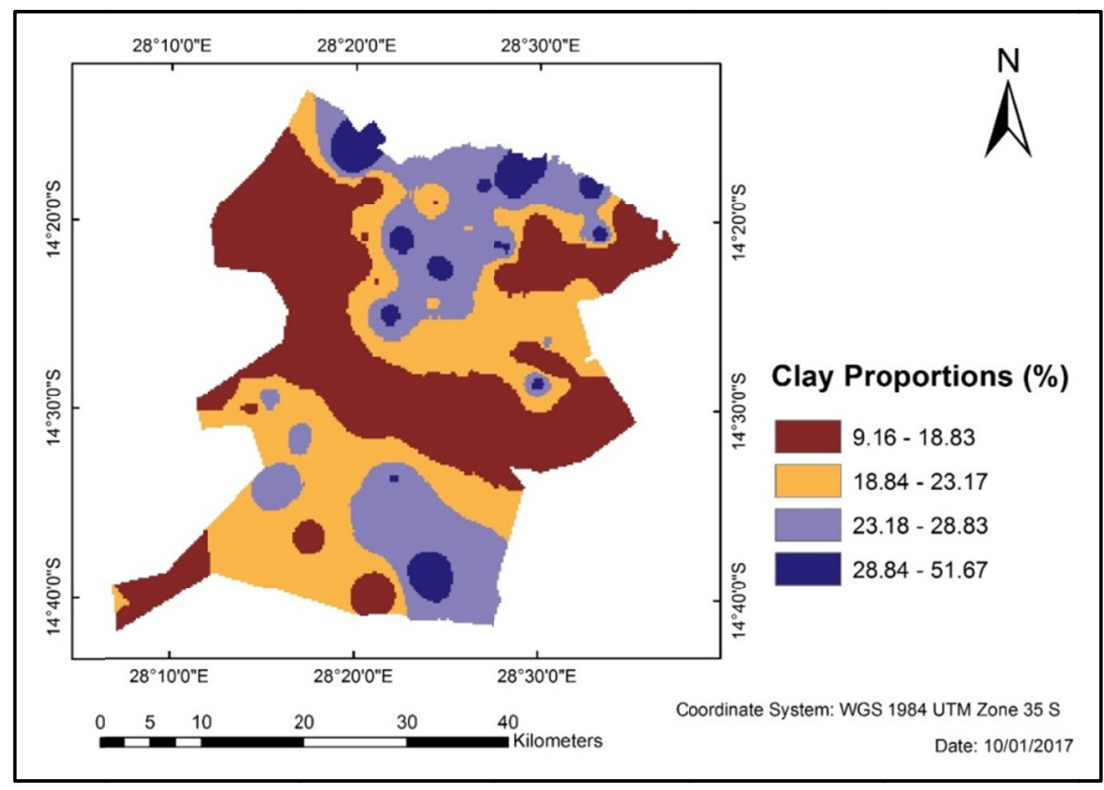

Figure 9. Map showing spatial variability of clay proportions in the soils in Kabwe

\subsubsection{Distance to Roads}

In addition to the biophysical factors, accessibility represented by distance to roads was included as an attribute affecting land suitability. Distance determines the ease of crop movement and access to markets. The closer the area is to the access road, the more suitable it is for a particular land use. In this study, a distance to roads raster was created by first digitizing the major accessible roads from a 1:50,000 topographic sheet of Kabwe. The euclidean distance tool was used to create the distance dataset, with a shapefile for the roads used as an input feature source data. The euclidean distance is one of the tools that describe the relationship of each cell in a raster to a source or a set of sources based on the straight-line distance. In particular, euclidean distance gives the distance from each cell in the raster to the closest source. In this study, it was used to calculate the distance from the cells in the roads raster to the closest suitability class. The area close to the road was therefore classified as most suitable 
based on distance factor. The generated distance grid was classified into three classes based on soybean suitability (Figure 10).

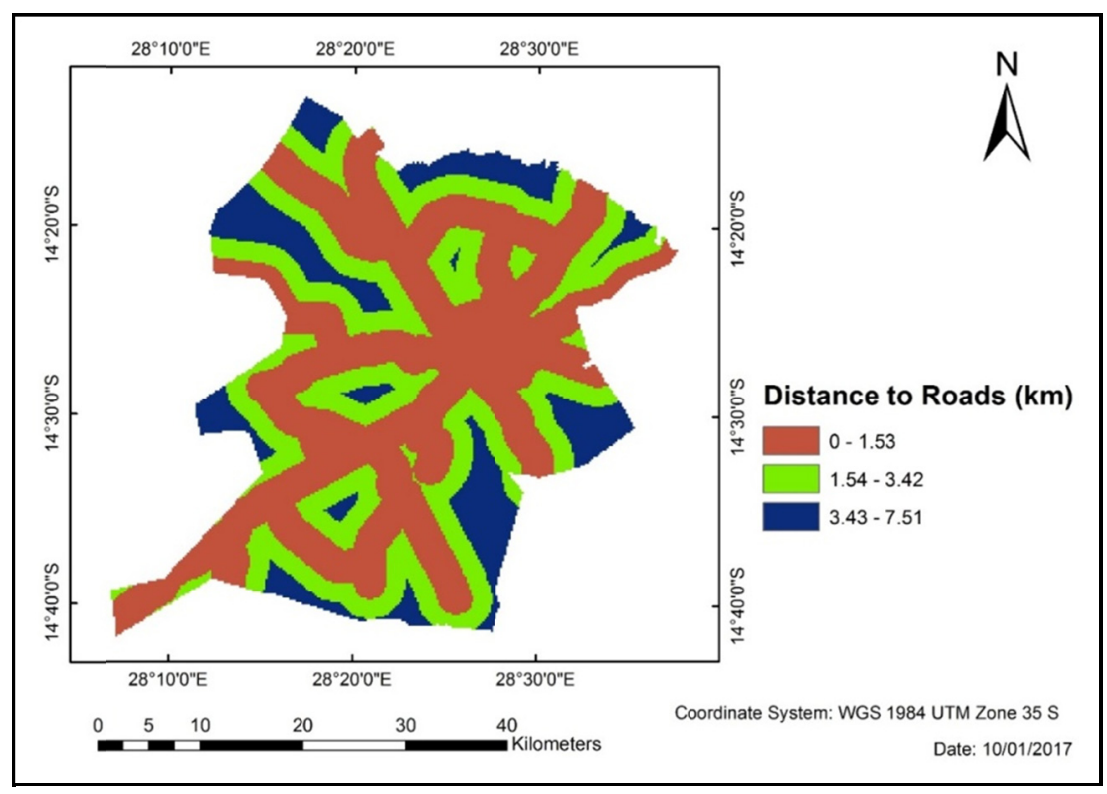

Figure 10. Distance to the roads raster

\subsection{Reclassifying, Weighting and Overlaying Datasets}

The raster data layers were in different numbering systems and could not be successfully combined in the overlay. The data layers were therefore reclassified from their different numbering systems to a common scale. The different factors used in analyzing land suitability may also not be equally important in choosing land suitability for soybean production. These factors were therefore ranked and assigned weights based on their varying degree of influence on land suitability for soybean production (Table 1). Equation 4 was used to calculate the relative weight or importance for each attribute in soybean production. In the equation, $\mathrm{W}_{\mathrm{i}}$ is the weighting for criterion $\mathrm{i}, \mathrm{n}$ is the number of criterion and $\mathrm{k}$ is a counter for summing across all criteria (Bolstad, 2005).

$$
\mathrm{W}_{\mathrm{i}}=\left(\mathrm{n}-\mathrm{r}_{\mathrm{i}}+1\right) / \Sigma\left(\mathrm{n}-\mathrm{r}_{\mathrm{k}}+1\right)
$$

Table 1. Weighting of selected attributes relevant for soybean production

\begin{tabular}{llll}
\hline CRITERION & RANK & NUMERATOR $\left(\mathrm{n}-\mathrm{r}_{\mathrm{i}}+1\right)$ & WEIGHT $\left(\mathrm{n}-\mathrm{r}_{\mathrm{i}}+1\right) / \sum\left(\mathrm{n}-\mathrm{r}_{\mathrm{k}}+1\right)$ \\
\hline Organic Carbon & 2 & $8-2+1=7$ & $7 / 58=0.12$ \\
Phosphorus & 2 & $8-2+1=7$ & $7 / 58=0.12$ \\
$\mathrm{pH}$ & 2 & $8-2+1=7$ & $7 / 58=0.12$ \\
Texture & 2 & $8-2+1=7$ & $7 / 58=0.12$ \\
Slope & 1 & $8-1+1=8$ & $8 / 58=0.14$ \\
Drainage & 1 & $8-1+1=8$ & $8 / 58=0.14$ \\
Elevation (Proxy for Climate) & 1 & $8-1+1=8$ & $8 / 58=0.14$ \\
Road & 3 & $8-3+1=6$ & $6 / 58=0.10$ \\
SUM TOTAL & & 58 & 1 \\
\hline
\end{tabular}

\subsection{Land Capability Analysis}

In order to identify the main limiting factors for crop production in the area, a land capability evaluation was performed by combining all the reclassified data layers except for the distance dataset using the cell statistic tool. 
The main limiting factors were identified to help small scale farmers develop crop management practices that will help increase soybean productivity (Rabia, 2012).

\subsection{Generating the Land Suitability Map for Soybean Production}

The reclassified and weighted data layers were combined using the weighted sum overlay tool. Weighted overlay is a method for applying a common scale of values to a number of different input data to create an integrated analysis (Malczewski, 2004). The principle in weighted sum overlay is that, the cell values or rating of suitability class of each input are multiplied by the raster's weight, which is the criteria weights. The resulting cell values are added to produce the final output raster or suitability map. In this study, the resultant of the weighted sum overlay was a land suitability map for soybean production. The map classified the study area into six land suitability classes for soybean production. These classes were identified as highly suitable, suitable, moderately suitable, marginally suitable, currently not suitable and permanently not suitable.

\subsection{Validation of the Suitability Map}

Ground truth data was used to validate the land suitability map. A field visit was undertaken to farms where soybean production is practiced. Information on land suitability and soybean production was gathered by interviewing the farmers in the area while taking note of the physical attributes of each farm visited. The data collected was used to construct an error matrix which was used to calculate the map accuracy by comparing the number of correctly verified points in the field and the predicted data on the generated land suitability map.

\section{Results and Discussion}

\subsection{Spatial Variation of Selected Attributes Relevant for Mapping Soybean Land Suitability}

\subsubsection{Slope, Drainage and Elevation (Proxy for Climate)}

The spatial variation showed that $92.62 \%$ of the land in Kabwe is almost flat characterized by slope ranging from $0 \%$ to $3 \%$. This area was rated suitable for soybean production with regards to slope. Steep slope greater than $5 \%$ was also recorded near hilly areas covering $1.45 \%$ of the total investigated area (Figure 3). Similar results were obtained by Woode and Mwenda (1988) where the area in the extreme north of Kabwe was found to be steep and therefore recommended land levelling in that area for successful crop production.

Results further showed that, there was less soil moisture in the area lying on higher points which was characterized by high percent slope. This was due to less accumulation. At these points, water usually flow out to other points, therefore soybean production may be hindered in this area. Soybean only requires enough soil moisture to effect growth. In terms of soil moisture, $44.76 \%$ of the total area was classified as suitable, moderately suitable and marginally suitable with enough soil moisture to support soybean growth. The area with high accumulation and with no accumulation may get flooded or extremely dry respectively and was therefore classified as not suitable for soybean production. Soybean growth is hindered in this area unless soil moisture management is employed. High accumulation area with wetness index greater than 19.64 was classified as rivers and streams covering $3.40 \%$ of the total area (Figure 4).

Four elevation classes were generated according to soybean suitability with $50.99 \%$ of the investigated area rated as suitable and $33.66 \%$ as moderately suitable for soybean production with regards to weather conditions experienced. Relating elevation to climate (rainfall and temperature), results showed that the area with elevation between $1195 \mathrm{~m}$ and $1337 \mathrm{~m}$ was associated with severe weather conditions, covering $15.34 \%$ of the total area (Figure 5). This area was mostly lying on higher points characterized by hills, and therefore rated as currently not suitable for soybean production. The rest of the area covering $84.66 \%$ of the total area was characterized by favorable to moderate weather conditions with elevation ranging between $1110 \mathrm{~m}$ and $1195 \mathrm{~m}$.

\subsubsection{Soil Attributes}

The spatial variation showed that soil reaction was a limiting factor to soybean production with most of the area characterized by soils with low pH values. The soil reaction mapping by Mambo and Phiri (2004) also showed that Kabwe district area is characterized by soils with low $\mathrm{pH}$ values. Soybean growth requires soil $\mathrm{pH}$ range of 5.6 to 7 , and results from this study show that only $0.62 \%$ of the investigated area was characterized by soils in this $\mathrm{pH}$ range indicating slightly acidic soil. Results further showed that $73.88 \%$ of the area was characterized by strongly acidic soils with $\mathrm{pH}$ values ranging from 4.51 to 5.0 (Figure 6). This area was rated as marginally suitable for soybean production in terms of soil reaction $(\mathrm{pH})$, requiring application of agricultural lime to improve soybean yields. The other $18.43 \%$ of the area was characterized by very strongly acidic soils having $\mathrm{pH}$ values ranging from 4.02 to 4.5 . This area was rated as currently not suitable for soybean production. 
Results further showed that, only $19.55 \%$ of the total area was characterized by soils having moderate to high amounts of organic carbon (Figure 7). The rest of the area was characterized by less than $1 \%$ of organic carbon in the soil and this may affect the fertility of the soil. It is therefore important that management practices to improve organic matter in the soil are employed to enhance soybean production in Kabwe.

A total of $86.15 \%$ of the area was characterized by soils having less than $10.85 \mathrm{ppm}$ of available phosphorus (Figure 8). Similar results were obtained by Sokotela (1982) and Banda et al. (1986) showing that most of the soil in Kabwe is characterized by less amounts of available phosphorus below the critical limit of $10 \mathrm{ppm}$. Agriculture crops including soybean requires about $10 \mathrm{ppm}$ of phosphorus or more for effective growth. In this study, only $13.85 \%$ of the total area was characterized by soils having more than $10.85 \mathrm{ppm}$ of available phosphorus. The lack of phosphorus in crops may prevent other nutrients from being acquired because phosphorus has a stimulating effect on root growth since it is usually concentrated in the root tips of most plants (Linda et al., 2015).

Spatial variation of sol texture showed that Kabwe area was characterized by soils having clay proportions ranging between $9.16 \%$ and $51.67 \%$ (Figure 9). Generally, the best agriculture soils for crop production are those containing 10 to 20 percent clay. Soybean on the other hand requires deep and well drained soils varying in texture from sandy, sandy loams to clay loams. Dugje et al. (2009) also noted that the best soil for optimum soybean production is a loose, well-drained loam with less clay fractions.

The soil texture identified in the area consists of sandy (S), loam (L), sandy loam (SL) and silty loam (SiL) soils with concentration of clay proportions ranging between $9.16 \%$ and $23.17 \%$ (Figure 9). These soils were rated as suitable for soybean production, covering $72.07 \%$ of the total area. The other area was characterized by soil having clay proportions ranging between $23.18 \%$ and $51.67 \%$, rated as moderately suitable for soybean production. This area comprised of medium textured soils, moderately fine textured to fine textured soils and clayey soils, including clay loam (CL), sandy clay loam (SCL), silt loam (SiL) and silt clay (SiC) soils. The soils with more clay content were mostly those distributed around water areas such as on the river banks.

It was also shown that must of the area was accessible with $50.52 \%$ of the total area located close to access roads within a distance of $1.53 \mathrm{~km}$. Hence the ease of transportation of inputs and access to the market.

\subsection{Suitability Analysis for Soybean Production}

Based on the weighted attributes, the suitability map for soybean was generated showing the different levels of suitability (Figure 11). Results for the qualitative land suitability analysis showed that $87.35 \%$ of the total area was suitable for soybean production, of which $15.07 \%$ was highly suitable having no limitation, $26.53 \%$ was suitable with minor limitations and $25.18 \%$ was moderately suitable with moderate limitations (Figure 11; Table 2). The other $20.57 \%$ was marginally suitable having moderately severe limitations. Results further showed that $12.66 \%$ of the area was not suitable for soybean production of which $10.74 \%$ was currently not suitable with severe limitations and $1.92 \%$ was permanently not suitable with extremely severe limitations.

A land capability assessment showed that the area in Kabwe has some limitations owing to different factors including soil reaction, low levels of available phosphorus low SOC, and to a lesser extent owing to slope. This indicated that there was no land that could be classified as highly suitable with no limitations or with insignificant limitations. However, results from this study, showed that $15.07 \%$ of the area was highly suitable contrary to the results obtained in a land capability assessment. This was attributed to the fact that only the biophysical factors were considered in land capability assessment while suitability assessment included accessibility as a non-biophysical factor. The non-biophysical factors such as the social economic factors have an influence on the suitability of an area for a particular utilization, and are therefore considered in suitability mapping (FAO, 1976; Grose, 1999). 


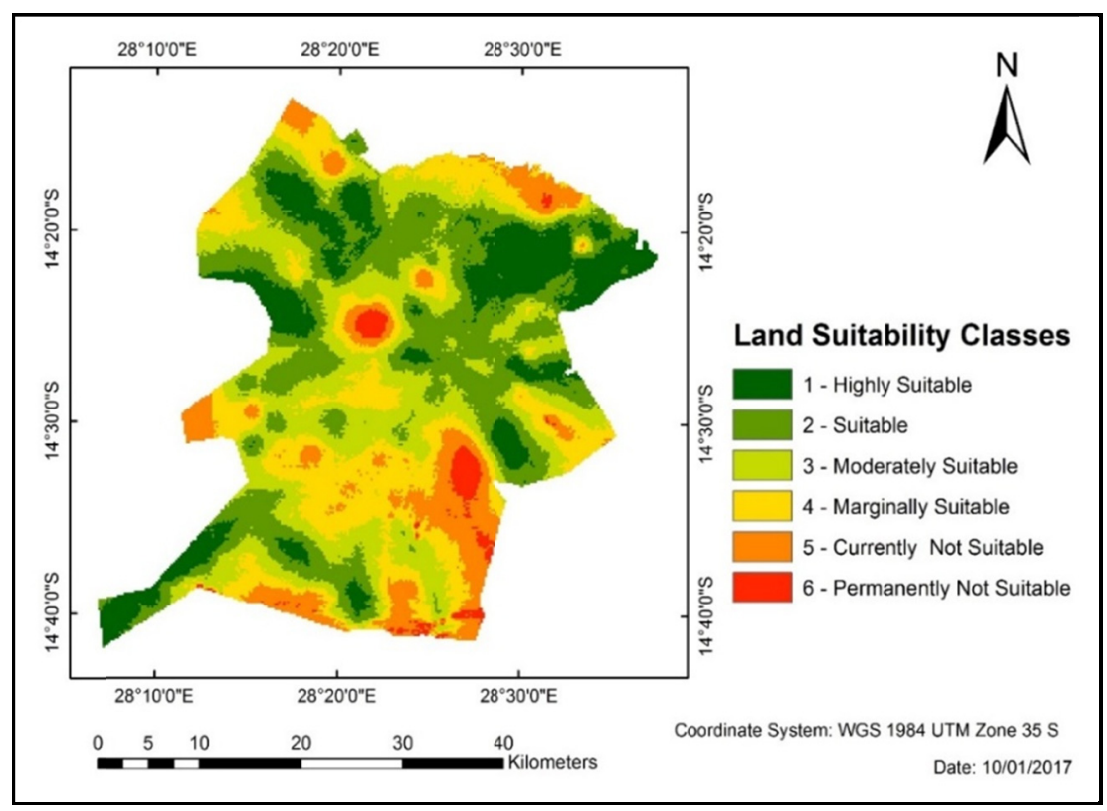

Figure 11. Land suitability map for soybean production in Kabwe

Table 2. Area covered in each suitability class

\begin{tabular}{llllll}
\hline \multirow{2}{*}{ Suitability Class and level limitations } & \multicolumn{3}{l}{ Area covered in land Suitability Map } & & \multicolumn{3}{l}{ Area covered in land Capability Map } \\
\cline { 2 - 3 } \cline { 5 - 6 } & $\%$ & ha & & $\%$ & ha \\
\hline Highly suitable/No Limitations & 15.07 & 23585 & & 0 & 0 \\
Suitable/Minor Limitations & 26.53 & 41519 & & 0.01 & 16 \\
Moderately Suitable/Moderate Limitations & 25.18 & 39407 & & 9.34 & 14617 \\
Marginally Suitable/Moderately Severe Limitations & 20.57 & 32192 & & 37.13 & 58109 \\
Currently Not Suitable/Severe limitations & 10.74 & 16808 & & 53.13 & 83149 \\
Permanently Not Suitable/Extremely Severe Limitations & 1.92 & 3005 & & 0.31 & 485 \\
TOTAL & 100 & 156500 & & 100 & 156500 \\
\hline
\end{tabular}

\subsection{Validation of the Suitability Map for Soybean Production}

Based on ground truth data, the overall classification accuracy of the suitability map was $65 \%$ (Table 3 ). At this percent accuracy, this map (Figure 11) can rightly be used by small scale farmers growing soybean and other land users for decision making. The accuracy for each suitability class in this study was $70 \%$ for highly suitable, $60 \%$ for suitable, $77 \%$ for moderately suitable and $57 \%$ for marginally suitable. Results further showed that the accuracy for the currently not suitable and permanently not suitable classes was $60 \%$ for each.

Table 3. Error matrix showing classification accuracy of the suitability map

\begin{tabular}{llll}
\hline Suitability Class & Points Verified & Correctly Classified Points & \% Of Correctly Classified Points \\
\hline Highly Suitable & 30 & 21 & 70 \\
Suitable & 30 & 18 & 60 \\
Moderately Suitable & 30 & 23 & 77 \\
Marginally Suitable & 30 & 17 & 57 \\
Currently Not Suitable & 10 & 6 & 60 \\
Permanently Not Suitable & 5 & 3 & 60 \\
Total & 135 & 88 & 65 \\
\hline
\end{tabular}




\section{Conclusion}

Based on the findings of this study, it can be concluded that Kabwe has great potential for soybean production. The generated land suitability map, showed that $87.35 \%$ of the total area in Kabwe is suitable for soybean production. The other $12.66 \%$ is not suitable owing to different limiting factors. The main limitations to soybean production in Kabwe as identified in the land capability analysis are soil reaction and available phosphorus. Therefore, application of phosphate fertilizers to address low available phosphorus and agriculture lime to correct soil acidity is necessary to enhance soybean production in the area. It can further be concluded that the generated land suitability map with overall classification accuracy of $65 \%$ can rightly be used as a guide in decision making for soya bean production. This study therefore demonstrated that a GIS based multi-criteria analysis can be considered as an important tool for delineating land suitability for soybean production.

It is recommended that future studies can apply this method for mapping land suitability with addition of other parameters that were not included in this study. The method can also be used to map land suitability for other crops such as cereals. Field trials can also be set up in the various suitability classes as identified in the study. This will allow for testing of the various management options for optimal soybean production in each of the suitability classes.

\section{Acknowledgements}

The author is thankful to the Agricultural Productivity Programme for Southern Africa (APPSA) for the financial support.

\section{References}

Adornado, H. A., \& Yoshida, M. (2008). Crop Suitability and Soil Fertility Mapping using Geographic Information System (GIS). Agricultural Information Research, 17(2), 60-68. https://doi.org/10.3173/ air.17.60

Banda, D. J., Chongo, G., \& Meeren, C. V. D. (1986). Semi-Detailed Soil Survey of Ronwell Farm: (Farm Nos. 797 and 3255, Kabwe, Central province. Soil Survey Report No. 135. Soil Survey Unit, Department of Agriculture, Zambia.

Beven, K. J., \& Kirby, M. J. (1979). A physically based, variable contributing area model of basin hydrology. Hydrological Science Bulletin, 24, 43-69. https://doi.org/10.1080/02626667909491834

Bolstad, P. (2005). GIS Fundamentals: A First Text on Geographic Information System (2nd ed.). Eider Press, USA.

Chabala, L. M., Mulolwa, A., \& Lungu, O. (2013). Landform classification for digital soil mapping in the Choongwe-Rufunsa area, Zambia. Agriculture, Forestry and Fisheries, 2(4), 156-160. https://doi.org/ 10.11648/j.aff.20130204.11

Chinene, V. R. N. (1991). The Zambian Land Evaluation System. Soil Use and Management, 7(1), 21-29. https://doi.org/10.1111/j.1475-2743.1991.tb00841.x

Clayton, D. B. (1974). Reconnaissance Soil Survey: Mukonchi East Block (Western Half). Soil Survey Report No. 21. Soil Survey Unit, Land Use Branch, Department of Agriculture, Zambia.

Dugje, I. Y., Omoigui, L. O., Ekeleme, F., Bandyopadhyay, R., Kumar, P. L., \& Kamara, A. Y. (2009). Farmers' Guide to Soybean Production in Northern Nigeria. International Institute of Tropical Agriculture (IITA), Ibadan, Nigeria. Retrieved November 29, 2016, from http://www.iita.org/c/document_library/get_fil e?p_1_id $=25368 \&$ folderId $=25529 \&$ name $=$ DLFE-192.pdf

Elsheikh, R., Sharrif, A. R. B. M., Amiri, F., Ahmad, N. B., Balasundram, S. K., \& Soom, M. A. M. (2013). Agriculture Land Suitability Evaluator (ALSE): A decision and planning support tool for tropical and subtropical crops. Computer and Electronics in Agriculture, 93, 98-110. http://dx.doi.org/10.1016/j.compag. 2013.02.003

English, C. (1982). Semi-Detailed Soil and Land Capability Survey of Liteta Leprosarium, Central Province. Soil Survey Report No. 101. Soil Survey Unit, Land Use Branch, Department of Agriculture, Zambia.

FAO. (1976). A Framework for Land Evaluation: Food and Agriculture Organization. Soils Bulletin No. 32. Rome, Italy.

FAO. (1983). Guidelines: Land Evaluation for Rain fed Agriculture, Food and Agriculture Organization. Soils Bulletin No. 52, Rome, Italy. 
FAO. (2007). Land Evaluation: Towards a revised framework. Land and Water Discussion Paper 6. Rome, Italy.

Grose, C. J. (1999). Land Capability Handbook: Guidelines for the Classification of Agricultural Land in Tasmania (2nd ed.). Foot and Playsted, Launceston, Tasmania.

Kabwe Municipal Council. (2010). Kabwe District State of Environmental Outlook Report Kabwe, Zambia.

Kalima, C., \& Veldkamp, W. J. (1985). Land Evaluation Methodology of the Zambia Soil Survey Unit. In P. R. Woode (Ed.), Proceedings of the XI th International Forum on Soil Taxonomy and Agro-technological Transfer (pp. 148-157). Zambia.

Kanangi, G. A. D., Yohane, E., Siyeni, D., Kachulu, L., Mtambo, L., Chisama, B. F., ... Mulekano, O. (2013). A Guide to Soybean Production in Malawi. Department of Agricultural Research Services (DARS), Lilongwe, Malawi. Retrieved November 29, 2016, from https://www.researchgate.net/publication/265736526_A_guid e_to_soybean_production_in_Malawi

Linda, A., Oluwatola, A., \& Opeyemi, T. A. (2015). Land Suitability Analysis for Maize Production in Egbeda Local Government Area of Oyo State Using GIS Techniques. International Journal of Biological, Biomolecular, Agricultural, Food and Biotechnological Engineering, 9(3), 280-285. Retrieved November 20, 2016, from http://www.waset.org/publications/10000819

Lubungu, M., Burke, W. J., \& Sitko, N. J. (2013). Analysis of the Soya Bean Value Chain in Zambia's Eastern Province. Working Paper 74. Indaba Agricultural Policy Research Institute (IAPRI), Lusaka, Zambia. Retrieved September 14, 2016, from http://www.iapri.org.zm

MAL. (2016). The Crop Forecasting Survey Report for the 2015/2016 Agriculture Season. Republic of Zambia.

Malczewski, J. (2004). GIS-based land-use suitability analysis: a critical overview. Progress in Planning, 62(1), 3-65. https://doi.org/10.1016/j.progress.2003.09.002

Malczewski, J. (2006). Ordered weighted averaging with fuzzy quantifiers: GIS-based multi criteria evaluation for land-use suitability analysis. International Journal of Applied Earth Observation and Geoinformation, 8(4), 270-277. https://doi.org/10.1016/j.jag.2006.01.003

Mambo, A., \& Phiri, L. K. (2004). Soil Acidity Map of Zambia. Zambia Agriculture Research Institute, Lusaka, Zambia.

Mendas, A., \& Delali, A. (2012). Integration of Multi-Criteria Decision Analysis in GIS to develop land suitability for agriculture: Application to durum wheat cultivation in the region of Mleta in Algeria. Computers and Electronics in Agriculture, 83, 117-126. https://doi.org/10.1016/j.compag.2012.02.003

MoA. (2002). Soybean Production Guide. Soils and Research Branch of the Ministry of Agriculture, Republic of Zambia.

Muliokela, S. W. (1995). Zambia Seed Technology Handbook. Ministry of Agriculture, Food and Fisheries, Zambia.

Mustafa, A. A., Man, S., Sahoo, R. N., Nayan, A., Manoj, K., Sarangi, A., \& Mishra, A. K. (2011). Land suitability analysis for different crops. A multi criteria decision making approach using remote sensing and GIS. Indian Agricultural Research Institute, New Delhi. Retrieved November, 29, 2016, from http://www.sciencepub.net/researcher/research0312/014_7181research0312_61_84.pdf

NAIS. (2015). The Crop Forecasting Survey for the 2014/2015 Agricultural Season and the Food Balance Status for the 2015/2016 Marketing Season. Agriculture Minister's Speech, Republic of Zambia.

Perveen, S., Arsalan, M. H., Siddiqui, M. H., Khan, I. A., Anjum, S., \& Abid, M. (2013). GIS Based Multi-Criteria Model for Cotton Crop Land Suitability: A Perspective from Sindh Province of Pakistan. Fuuast J. Biol., 3(1), 31-37. Retrieved November 29, 2016, from https://fuuast.edu.pk/biology\%20journal/ images/pdfs/Volume\%203\%20(1)\%20June,\%202013/31-37\%20Faheem\%20siddiqui.pdf

Rabia, A. H. (2012). A GIS Based Land Suitability Assessment for Agricultural Planning in Kilte Awulaeo District, Ethopia. The 4th International Congress of ECSSS, EUROSOIL, Bari, Italy, 2012. Retrieved November 29, 2016, from http://works.bepress.com/ahmed_rabia/5

Rutherford, R. J. (2010). An Assessment of Rain-fed Crop Production Potential in South Africa's Neighboring Countries. Report No. P RSA 000/00/12510, Department of Water Affairs, Republic of South Africa. Retrieved November 29, 2016, from https://www.dwa.gov.za/Projects/crocodilemaintenance/Documents/ MOCWS\%20Reports/Crop\%20Production\%20Potential\%20Final.pdf 
Schmidt, F., \& Persson, A. (2003). Comparison of DEM Data Capture and Topographic Wetness Indices. Precision Agriculture, 4, 179-192. https://doi.org/10.1023/A:1024509322709

Sokotela, S. B. (1982). Detailed Soil and Land Capability Survey of Chief Liteta Proposed Multi-Purpose CO-OPR. Farm, Central Province. Soil Survey Report No. 92. Soil Survey Unit, Land Use Branch, Department of Agriculture, Zambia.

Subarna, D., Purwanto, M. Y. J., Murtilaksono, K. M., \& Wiweka. (2014). The relationship between monthly rainfall and Elevation in the Cisangkuy watershed Bandung Regency. International Journal of Latest Research in Science and Technology, 3(2), 55-60. Retreived November 29, 2016, from http://www.mnkjournals.com/ijlrst_files/Download/Vol\%203\%20Issue\%202/11-4-08032014\%20The\%20R elationship\%20Between $\% 20$ Monthly\%20Rainfall\%20and\%20Elevation\%20in\%20the $\% 20$ Cisangkuy\%20w atershed\%20Bandung\%20Regency.pd

Sullivan, P. (2003). Intercropping principles and production practices. Agronomy System Guide, Appropriate Technology Transfer for Rural Areas (ATTRA), Fayetteville. Retrieved November 29, 2016, from http://attra.ncat.org/attra-pub/intercrop.html

Tembo, S., \& Sitko, N. J. (2013). Technical Compendium: Descriptive Agricultural Statistical Analysis for Zambia. Working Paper. Lusaka: IAPRI. Retrieve November 29, 2016, from http://ageconsearch.umn.edu/ bitstream/155988/2/wp76.pdf

Veldkamp, W. J. (1987). Reconnaissance/Semi-detailed Semi-Quantified Land Evaluation System for Non-Irrigated Agriculture. Technical Guide No. 19. Soil Survey Unit Research Branch, Department of Agriculture, Lusaka, Zambia.

Wilson, J. P., \& Gallant, J. C. (2000). Terrain Analysis: Principles and Applications. John Wiley and Sons, Inc. New York.

Woode, P. (1979). Reconnaissance Soil Survey of Muswishi Rural Reconstruction Centre. Soil Survey Technical Report No. 60. Soil Survey Unit, Land Use Branch, Department of Agriculture, Zambia.

Woode, P. (1988). Field guide for soil surveyors. Technical Guide No. 18. Soil Survey Unit, Department of Agriculture, Zambia.

Woode, P., \& Mwenda, R. (1980). Semi-Detailed Soil Survey of Chibote Farms LTD: Farm Numbers 3571 and 3189, Kabwe District, Central Province. Soil Survey Report No. 61. Soil Survey Unit, Land Use Branch, Department of Agriculture, Zambia.

ZMD. (2015). Weather and Climate Reports-2015. Lusaka, Zambia.

\section{Copyrights}

Copyright for this article is retained by the author(s), with first publication rights granted to the journal.

This is an open-access article distributed under the terms and conditions of the Creative Commons Attribution license (http://creativecommons.org/licenses/by/4.0/). 